\title{
Public Health and Critical Ethnographies
}

\section{La salud pública y las etnografías críticas}

\author{
Diana Paola Betancurth-Loaiza(D) ${ }^{1}$, Luisa Fernanda Guarín-García(D2) , Juan Alejandro Holguín-Zuluaga(D)3 \\ 1. Universidad de Caldas. Manizales, Colombia. Correo: diana.betancurth@ucaldas.edu.co - https://orcid.org/0000-0001-7620-2336 \\ 2. Universidad de Caldas. Manizales, Colombia. Correo luisa.guarin.garcia@gmail.com - https://orcid.org/0000-0001-6734-9037 \\ 3. Universidad de Caldas, Manizales, Colombia. Correo: juan.holguin@ucaldas.edu.co - https://orcid.org/0000-0002-9711-3989
}

Typology: Review article

To cite this article: Betancurth-Loaiza DP, Guarín-García LF, Holguín-Zuluaga JA. Public health and critical ethnographies. Duazary. 2021 julio; 18(3): 295308. Doi: https://doi.org/10.21676/2389783X.4246

Received on November 18 of 2020

Accepted on May 14 of 2021

Published online August 03 of 2021

\begin{abstract}
Keywords: Ethnography; health; Public health; Critical thinking.

This article analyzes characteristic elements of public health as a disciplinary field in contrast to critical ethnography. We carry out an exploratory, integrative review between 2010 and 2020 in Spanish, English, and Portuguese. Health and social science databases were used, finding 620 relevant references, of which 64 were studied. The descriptors were ethnography, health, public health, social anthropology, and critical thinking. The articles were classified according to discipline and country of origin. Subsequently, we discuss the presence of ethnography in various public health works, the history of ethnographies, their diverse applications as methods, focus, social impact, and emancipation tools to demonstrate the existence of ethnographies. In conclusion, the main meeting points identified between public health and critical ethnographies were the visibility of researchers/professionals as subjects with whom research is conducted, the multidimensionality of the phenomena addressed, the recognition of issues that involve power tensions, the questioning of other knowledge, and the intention to carry out actions for communities to access health care.
\end{abstract}

\section{RESUMEN}

El escrito analiza elementos característicos de la salud pública como campo disciplinar en contraste con la etnografía crítica. Para ello, se realizó una revisión integrativa exploratoria, entre 2010 y 2020, en español, inglés y portugués. Se utilizaron bases de datos de salud y ciencias sociales, con hallazgo de 620 referencias relacionadas con la temática, de las cuales se estudiaron. Los descriptores fueron: etnografía, salud, salud pública, antropología social y pensamiento crítico. En los resultados se encontró que los artículos se clasificaron de acuerdo con su disciplina y país de origen. Posteriormente se construyeron apartados que recapitularon la presencia de la etnografía en los diversos trabajos de la salud pública, la historia de las etnografías, su diversidad de aplicación como método, enfoque, impacto social y herramientas de emancipación, cuestiones que demuestran la existencia de las etnografías. Se concluye que los principales puntos de encuentro identificados entre la salud pública y las etnografías críticas fueron: visibilización de los investigadores/profesionales como sujetos con quienes se investiga, multidimensionalidad de los fenómenos que se abordan, reivindicación de temas que involucran tensiones de poder, cuestionamiento de otros saberes y el propósito de llevar a cabo acciones para que las comunidades accedan a la salud. 


\section{INTRODUCCIÓN}

From the epistemic-ontological framework of disciplinary fields and methods, theoreticalmethodological orientations direct the relationships between researchers and their subjects, both individually and collectively, field data collection, the time spent in the field, the depth of the analysis, and even the presentation of results. Thus, the coherence that the researcher builds through who they are, what they know, and what they do should be highlighted.

As a discipline and practice, public health is a polysemic concept whose central theme is the health/disease/care process and encompasses three groups of meanings "as knowledge, as a practice and as a social reality," with ethical and political functions. It is not a homogeneous concept, and within it, there are also disagreements resulting from opposing interests ${ }^{1-4}$.

Conventional and hegemonic public health has concentrated its actions on the development of linear interventions. Health professionals act mainly from institutional and disciplinary scientific rationality; in their work, the truth based on positivist science predominates over everyday know-how as pragmatic knowledge, based on pathologies and excessive medicalization ${ }^{1,2}$. However, the dialogue between health sciences and social sciences has fostered a transformation in understanding health in relation to disease since it is now considered a social construct within daily life. This dialogue, in turn, has made it clear that public health needs to address structural conditions ${ }^{4}$ and not only health problems from a broader perspective.

Other forms of public health consider social experiences as resources to take action that stimulates learning and advance in a field of permanent construction that also questions reality. Therefore, it must lie in the recognition of historical, ontological, socio-cultural, political, economic, and biological contexts through symbolic and material expressions that affect all the relationships of the subjects ${ }^{4}$. Hence, qualitative methodological routes are required for this approach. This incursion has required methods such as ethnography, which is used by researchers from different health disciplines ${ }^{5}$ to carry out critical analyses, theoretical developments, and political inquiries ${ }^{6}$ based on the humanistic nature of health sciences. There is a need to access meanings, perceptions, beliefs, knowledge, and practices, from the approach not only to the morbid process-discomfort, suffering, ailments - but also to the socially determined daily life.

The origins of the ethnographic approach are related to immersion in the context of natives and their "exotic" ways of life and the recognition of the role of human action from their point of view with "objective" and "scientific" descriptions, where the researcher was the subject possessing knowledge ${ }^{7-}$ 10. Nonetheless, sociologists from the Chicago School proposed adaptations to classical ethnographies-a paradigm shift-for studying social groups in "modern" communities in the United States ${ }^{11}$. Moreover, the ethnographers focused on investigating daily life problems and understanding social reality ${ }^{12}$. These transformations gave rise to ethnographies with different epistemological and theoretical perspectives, ideas of culture, politics, and science, and conceptions of the human being-society relationship ${ }^{13-15}$ that have given rise to a more complex field of study. Thus, new forms of research emerged accompanied by critical hermeneutical positions that took on a political commitment to social change ${ }^{16}$ in defense of dialogical participatory research. They are helpful in making visible the differences between the powerful and the oppressed and the transformation of reality ${ }^{17-19}$ through political studies, interaction with social movements, and discussion of the academic culture ${ }^{20}$.

Critical ethnography has emancipatory implications and links knowledge to political action to address situations of injustice ${ }^{21}$.This activist stance provides a double reflection: rethinking the power relations immersed in the research and highlighting the interactions between structures of knowledge and powers ${ }^{22-24}$. Therefore, it can be affirmed that there 
is no single ethnography. Instead, ethnography can be conceived as a method or product ${ }^{8}$, a focus ${ }^{25-27}$, a social relationship ${ }^{28,29}$, a human emancipation tool $^{24,26}$, or more than a method ${ }^{30}$. In other words, because each ethnographer builds their own ethnography, multiple "ethnographies" are formed.

The standpoint on which this manuscript is based goes two ways. On the one hand, public health is polysemic due to multiple perspectives, and there is no single approach to ethnography since there is a wide range of positions whose understanding requires historical knowledge. Therefore, the purpose of this integrative review is to establish the relationships between public health as a disciplinary field and critical ethnography as a method based on categorization and comparative analysis. It also aims to identify their main meeting points, most important studies, contrasts, and complementarity.

\section{MATERIALS AND METHODS}

An exploratory, integrative review was carried out ${ }^{31}$ aimed at recovering characteristics of critical thinking. For the review, we followed several steps described by Tavares et $\mathrm{al}^{31}$ :

Preparation of the guiding question for the review: What is the relationship between public health as a disciplinary field and critical ethnography as a method?

Literature search: We searched PubMed, Science Direct, Virtual Health Library, Scopus, and Google Scholar for articles published between 2010 and 2020. In addition, we referred to several articles and books selected for their relevance. Master's theses and doctoral dissertations were also considered. The descriptors ethnography, health, public health, social anthropology, and critical thinking were used in Spanish, English, and Portuguese. The exclusion criteria were incomplete documents, bachelor's theses, and writings on other subjects.

Data collection: We identified 620 references. Of these, 567 were excluded, and 64 documents were selected, as shown in Figure 1.

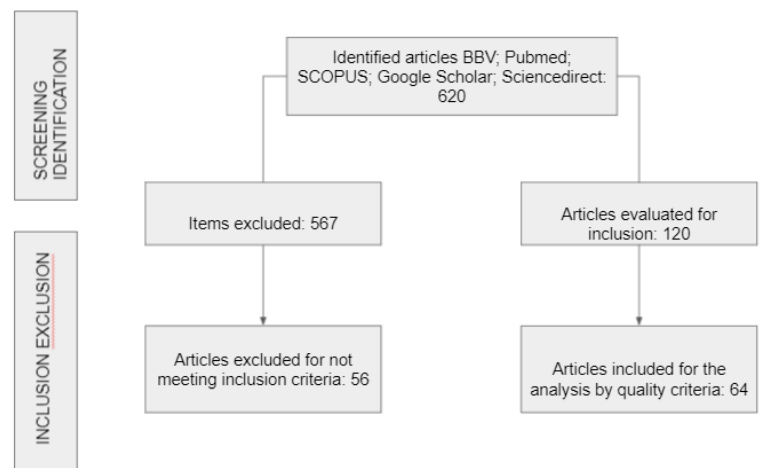

Figure 1. Findings in PubMed, Science Direct, Virtual Health Library, Scopus, and Google Scholar.

Critical analysis of included studies: We analyzed the selected articles for the quality of their contributions and relevance, the basis for consolidating trends, and the subject matter. They were organized in an Excel matrix with the following categories: generalities (author, text, discipline, type of document), epistemological and theoretical perspective, method (techniques, fieldwork, and writing), significant experiences in the approach, analysis of relationships (researcher participation and representation of the researched subject), and analytical relationships. Then, we designed relational tables to represent the comparative analysis and the points of agreement and disagreement.

Finally, regarding ethical considerations, according to Resolution 008430 of $1993^{32}$ by the Colombian Ministry of Health and the Declaration of Helsinki ${ }^{33}$ promulgated by the World Medical Association (WMA) in 2000, the study does not pose a risk as it is a review that only involves secondary sources as theoretical inputs for future research in the field.

\section{RESULTS}

The review draws on a total of 64 references, which come from countries such as the United States (18), Colombia (14), Mexico (8), and Argentina (5) (Figure 2). In them, qualitative ethnographic research has been applied to various topics and disciplines such as anthropology (28), nursing (15), medicine (8), sociology (4), psychology (3), public health (3), and education sciences (3) (Figure 3 ). 


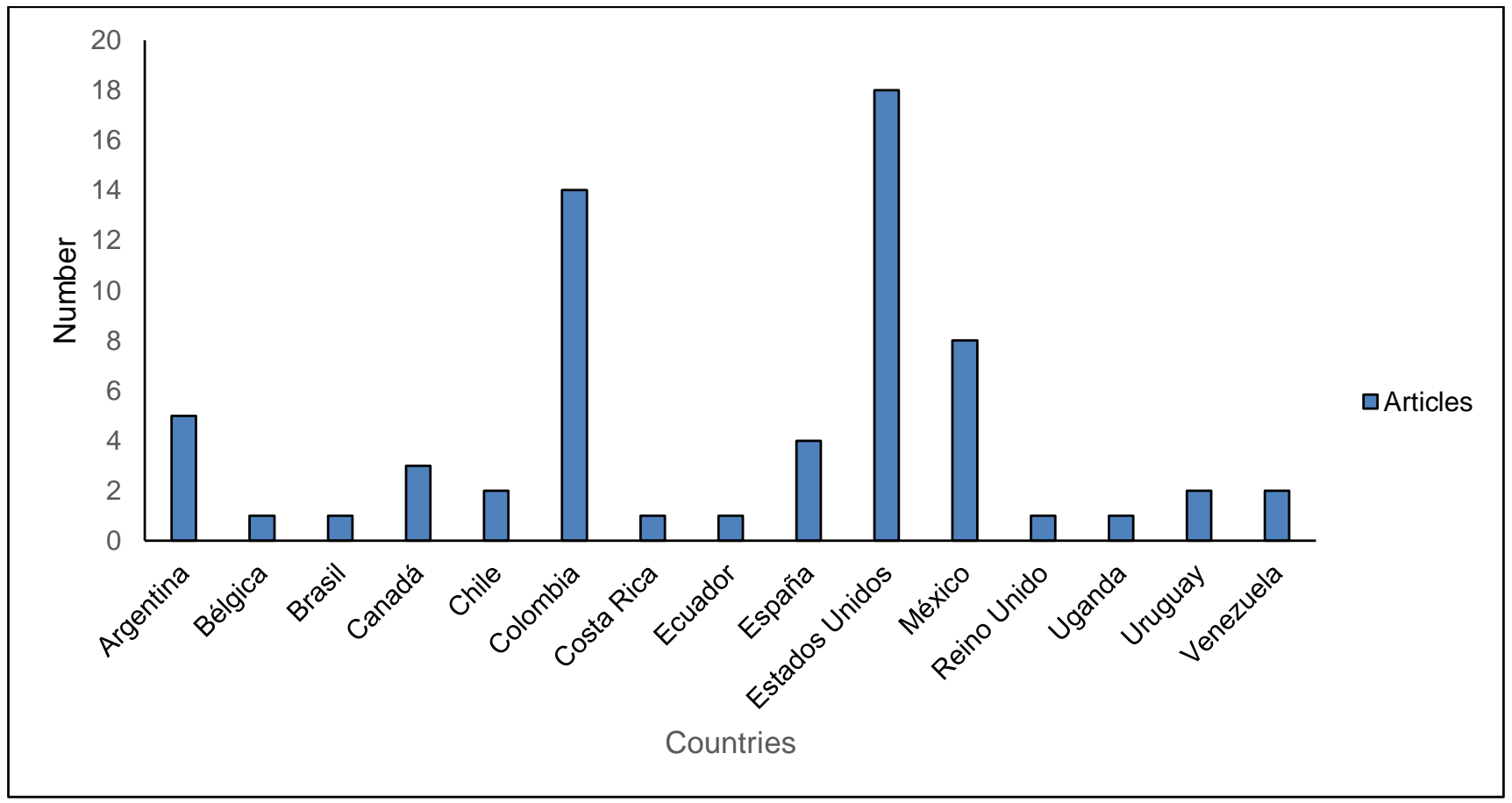

Figure 2. Distribution of articles by country.

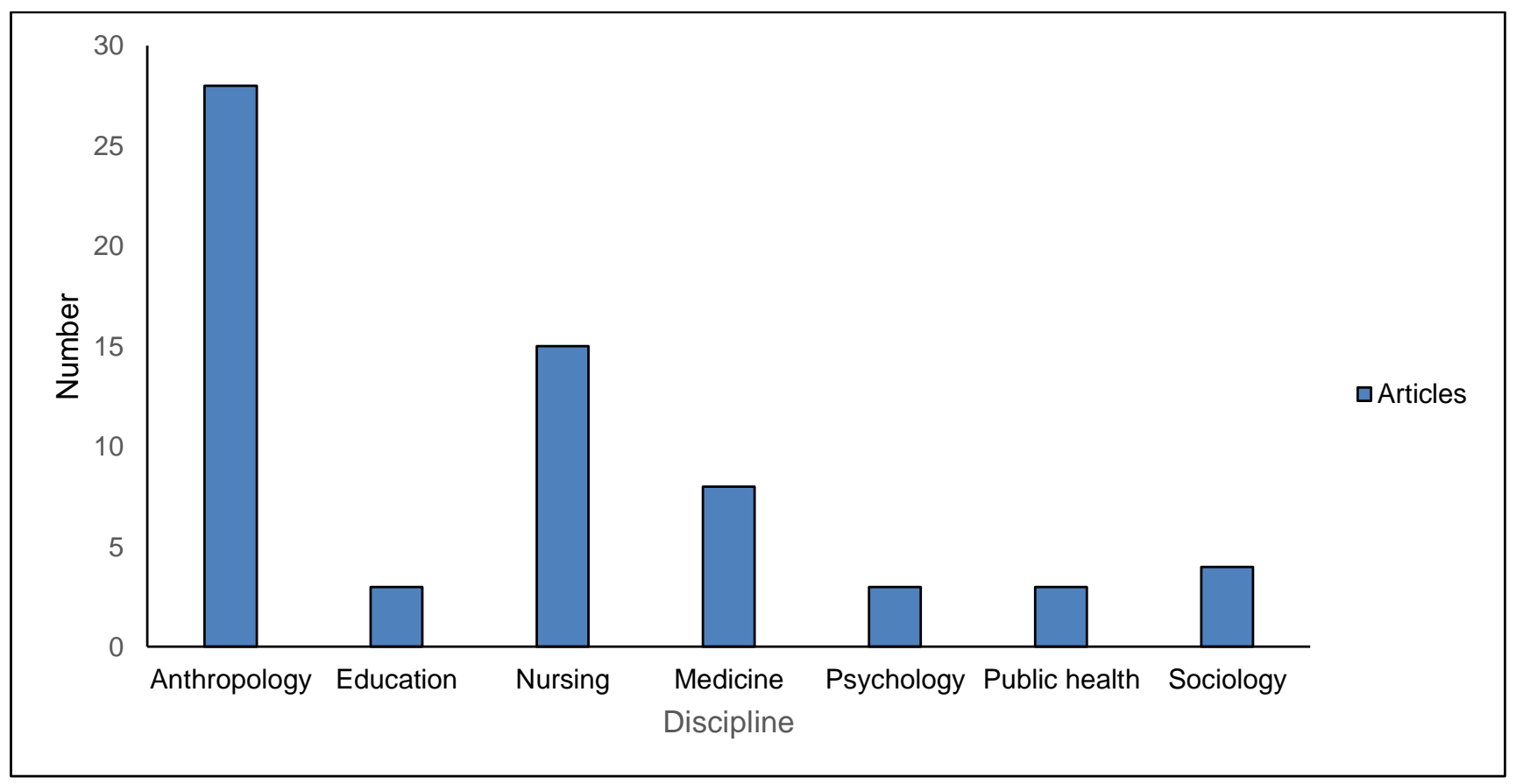

Figure 3. Distribution of articles by discipline. 
The analysis of the disciplines of the selected texts showed the diverse themes to which critical ethnography contributes. For example, from the reviewed anthropology studies, the characteristics of the method include participant observation as a critical practice in research ${ }^{8}$, double-reflexivity ${ }^{22}$, writing performance ${ }^{20}$, the collaboration and coauthorship of the subjects with whom the research is conducted $^{19}$, and its application to the problematization of public policies ${ }^{27}$.

Similar constructions appear in the sociological articles, which delve into the representation, reflexivity ${ }^{34}$, and inclusion of the gender perspective $^{35}$, a subject studied through psychology ${ }^{36}$. Concerning education as a disciplinary area, the reviewed studies focused on the compilation and reflection of ethnography in qualitative research ${ }^{37}$, the emergence of its critical orientations ${ }^{15}$, and the application of its knowledge to strengthen the training of human talent in health care $^{38}$.

Ethnography has contributed mainly to health studies. Some medical anthropology approaches have allowed analyzing health and disease processes from the perspective of the subjects ${ }^{11}$. They enable us to understand, for example, the various mental health problems in minority and ethnic groups ${ }^{39}$, the care of people with chronic diseases such as diabetes ${ }^{40}$, the relationships between women in labor and health personnel ${ }^{41}$, and the racialization and gender theories in health practices $^{42}$.

Public health has also used ethnography to interpret the relationships between subject, society, and culture, as noted in maternal education programs in health clinics ${ }^{43}$, growth and development programs ${ }^{44}$, health practices in communities ${ }^{45}$ that promote the health and quality of life of mothers to preadolescents ${ }^{46}$, health practices of the adolescent population in school, the perception of access to mental health services ${ }^{47}$, and nursing care ${ }^{48}$.

\section{Critical ethnographies and public health}

The texts analyzed were also classified according to their subject matter: public health, mental health, care policies, and gender perspective, thus complementing the review. The ethnographic approach, particularly the critical perspective, has contributed to public health and health education interventions from a dialogical model based on multidimensionality, bidirectionality, and symmetry. It has provided an empirical basis that considers social participation in health, which is possible because ethnography gives voice to patient-subjects and descriptions that can contradict representations based on dominant ideologies ${ }^{11}$.

Critical ethnography gains value by providing information about patients and health personnel's narratives, meanings, and experiences. Therefore, the contribution of ethnography is to juxtapose the results of its observation with the proposals by different actors responsible for official interventions, practices, and discourses ${ }^{49}$. Part of this conceptual tension that critical ethnography puts forward reveals social conditions such as the racialization of health actions and the discrimination of specific populations, which, together with the socio-historical and socio-environmental conditions, become social determinants of health ${ }^{27}$.

Critical ethnography is also applied to the design of health policies aimed at preventing and controlling infections during health care to overcome technical views and understand the behaviors of teams ${ }^{50}$. Unlike the other ethnographies, this perspective monitors the interpretation of community's needs and the researcher's reflexivity to prevent the information from consolidating interventions that expose vulnerable groups to greater discrimination ${ }^{51}$.

Mental health is another area in which critical ethnography is employed. Studies such as Sandoval's $s^{52}$ discuss how some care practices include the historical memory of individuals and acknowledge how their complicated lives can cause depression, anxiety, and other diseases. Critical ethnography also offers tools for analyzing mental health in non-dominant ethnic groups ${ }^{39}$.

Care as a category of public health is also permeated by critical ethnography. Specific studies stand out,

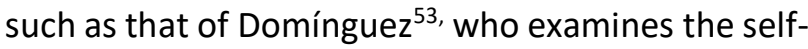


care of diabetic patients, the meanings of the disease, and gender from a critical anthropological perspective. McCabe and Holmes ${ }^{54}$ explore the experiences of nurses who care for young people with disabilities. The aim is to reflect on how their care practices can reproduce social limitations, stereotypes, heteronormativity, and prejudices concerning disability and sexual health. Works such as Buitrago' $s^{55}$ also deal with care in situations of disability but denounce how this field has been commercialized by Colombian state and private institutions and social organizations.

There are dissertations related to the care of health personnel, including Harrowing and Mikk's ${ }^{56}$. These authors use their ethnographic findings to account for nurses' moral anguish and coping strategies and patients who live with the Human Immunodeficiency Virus (HIV). The research can be related to Medina Castro ${ }^{57}$, who analyzes the experience of 17 nurses and outlines theoretical and practical proposals for understanding and learning about self-care.

Regarding care as part of raising children in vulnerable situations, Betancurth and Peñaranda ${ }^{58,59}$, Bedoya et $\mathrm{al}^{60}$, described the complex social contexts of caregivers and mothers, the impact on their life stories, practices, and even the relationship between their social class and the care they provide. The purpose was to unravel a network of injustices perpetuated by hegemonic discourses of traditional public health or the implementation of public policies that ignore social injustice settings.

Discussions about care opened the door to another issue highlighted by critical ethnography: the gender perspective, which has gained momentum in recent years with analyses that acknowledge the experiences and meanings of sexuality and gender in young populations ${ }^{61}$. In the same way, research has emerged that points to understanding women's sexual diversities and the visibility of their rights and experiences regarding sexual health beyond reproductive mandates ${ }^{62}$. Finally, this critical ethnography orientation for the study of the gender perspective takes up contributions from bioethical theory and anthropology to comprehend the body and its cultural domestication, impacting the configuration of moral values and even gender ${ }^{63}$.

\section{DISCUSSION}

According to the results, ethnography has contributed to different disciplines, particularly public health, because it helps to understand the links of professional care, the comprehensive approach to people, patients' identification of problems, and the construction of knowledge to improve health actions. After all, it enables the analysis of health-disease processes associated with cultural and social aspects by understanding the behaviors and relationships immersed in health contexts.

\section{Critical ethnographies and alternative public health: Convergence for action}

There is an pressing need to overcome dominant, unidirectional, hegemonic, and quantitative models centered on structural functionalism. The changes in these last decades of globalization make it necessary to find new paths in public health and reclaim theoretical-practical elements to understand and act on the foundations of health and life, not only on disease. This shift implies interpreting culture, historical realities, and ways of exercising power and strengthening social action and new identities, which has to do with this plural and dialogical view essential to the alternative critical perspective. In this sense, ethnography enriches the health-disease analysis by regarding itself as a "process of progressive re-making that takes shape in and through the ups and downs of the researcher's epistemic positions ${ }^{\prime 64}$, allowing them to concentrate on understanding the action of the subjects in a relational, bidirectional, and symmetric analysis that looks into how things are, not how they should be. For this reason, "it returns to the processes of health, disease, and care, and their status as social facts" ${ }^{\prime 11}$.

The above requires looking for new proposals that combine and produce changes in micro-contexts coherently between ideological foundations, conceptions, technical-political actions, and their projection on society. This approach may derive 
from the orchestration between discipline (health and public health) and method (anthropology), reflecting the interdisciplinarity and complementarity of the fields and overcoming the constant disputes between radical positions. Therefore, the analysis of the main categories that emerge from the results is presented with the meeting points between alternative public health and critical ethnography, providing a guide for action and future research in the hope of rethinking a public health that dispenses with local realities. Understanding the ethnographic approach pluralistically and considering its critical perspectives to tackle public health research implies a review of health-disease processes, that is public health with which to reach meeting points from the following premises.

\section{Philosophical-theoretical assumption of health and life, without neglecting disease prevention}

Within the theoretical assumption (knowledge), and under the plurality of ethnographies arising from historical evolution, some common conceptual points stand out. An understanding of the different approaches to ethnography, as shown in the results, makes it possible to make out, through different studies, the close relationship between one type of ethnography-criticism-and the other or alternative public health posited.

First, the value of the individual is highlighted, given that the positivist and functionalist approaches to traditional public health exclude the individual as the generator of their knowledge and action because the main interest of public health is biological. The alternative current emphasizes that living beings are autopoietic, that is, they establish their norms and structures of self-production ${ }^{61}$, especially human populations, which contrasts with critical ethnography. The latter sees the researcher and the researched as subjects who co-construct in an immersed symmetric relationship, an eminently social and cultural process that goes beyond the conception of the other-the object-as being dominated.

Second, critical ethnography and public health are analyzed in the framework of life. In contrast, public health deems health as life and social reality, which requires expanding ways of knowing and understanding actual social problems and cultural relations and expressions. Although critical ethnographies on illness-death are available, the concern is not the isolated phenomenon but the need to reflect on and understand the goal of healing.

Third, "living promotes health, which is not only maintained through the absence of disease; health is an autonomous and supportive way of living, inherent in human culture, dependent on and conditioning the relationships established with nature, society, and the State" ${ }^{59}$. For authors such as Martínez ${ }^{11}$, health is not only the result of interventions; its exploration through public health requires the population's cultural and symbolic conception of health. In other words, critical ethnography revives voice and language, which are excluded by other methodologies.

\section{Methods that integrate various metaphors and propose diverse hermeneutics (including the positivist scientific approach) to account for natural activity, social action, and social structures}

The assumption of the method is relevant to analyze critical ethnography in the framework of public health, especially if ethnography is understood as a dialogical method that challenges the strategies of the so-called monological intervention models, predominant in the hegemonic approach to healthillness processes. The monological view of health interventions tends to dismiss the knowledge of communities and impose a representation of a rational, passive, depersonalized subject ${ }^{64,65}$ by transmitting one-way/one-dimensional information ${ }^{66}$ that subdues the action of the subjects and silences their voices.

This perspective is questioned by the critical ethnography applied to studies on mental health ${ }^{67}$ and public health policies when giving a detailed description ${ }^{68,69}$ that sets the context of the subjects in a multidimensional dialogic model, integrating cultural, social, economic, and political determinants to consolidate other alternatives for 
health ${ }^{70,71}$. At the same time, it denounces the use of ethnographic knowledge to develop programs that stigmatize populations in vulnerable situations (women, ethnic groups). In this way, academia can drive political action.

Critical ethnography enhances the reflexivity and positionality of the researcher, making them part of their study as a subject who interprets, with their own conceptions of the world, the realities they observe and describe ${ }^{50}$, as noted in studies on care, where health professionals, based on their experiences, understand their self-care strategies or co-construct meanings with the participants ${ }^{72-74}$. Neutrality, one-dimensionality, and subordination are overcome to empower ${ }^{75}$ the social groups in which they are involved. As a method, critical ethnography validates the subject/community with whom the research is conducted, conceiving them as capable of producing and reproducing knowledge beyond scientific discourses thanks to a multidimensional, holistic, and contextualized approach $^{76,77}$. For example, studies on gender perspective generated knowledge from consolidated forms of power ${ }^{78}$ in favor of recognizing minority rights.

\section{Social practices that integrate various actors and powers in addition to state power}

About this foundation, "the individual, the public or social movements that promote health socially control the fulfillment of the duties entrusted to the State, fight for its democratization, and enter into agreements/disagreements with supra and infranational powers" ${ }^{78}$. Thus, critical ethnography as a method questions the use of knowledge. From the approach to alternative public health, critical ethnography asks "why?" or "for whom?" on seeing the multiple political, economic, and social interests that take part in the well-being and health of communities. The purpose is to promote social mobilization and represent researchers and participants as active actors capable of transforming themselves and their realities.

\section{CONCLUSION}

The main meeting points identified between alternative public health and critical ethnography were the visibility of researchers/professionals as subjects with whom research is conducted, the multidimensionality of the phenomena being analyzed, the reclaiming of issues that involve power tensions, the questioning of other knowledge, and the intention to take action so that communities have access to health. The identification of these points allowed us to made an analysis from Granda's theoretical assumptions. First, it implies a view of health beyond the absence of disease, which requires an approach from life and social reality to understand the population's cultural, symbolic, and social conceptions, issues to which the consideration of phenomena by critical ethnography contributes. As a second condition, methods that can account for natural activity, social action, and social structures are required.

Accordingly, critical ethnography offers to different forms of public health a method that produces knowledge that is situated, co-constructed, reflective, and empowers the subjects to achieve health. Finally, concerning social practices, critical ethnography offers possibilities by actively questioning how to produce knowledge and its use and purpose in devising health strategies beyond the traditional ones belonging to hegemonic models. An alternative view of public health requires methods other than the traditional ones, which broaden the horizon in studying the healthdisease process as a continuum. These include researchers, health professionals, and communities in multidimensional and dialogic dynamics, unlike a one-dimensional, monological perspective typical of the hegemonic public health model.

In conclusion, critical ethnography builds an epistemologically coherent bridge with alternative public health since both reveal the logics of power that for years have denigrated knowledge, subjectivities, and ways of life for being alien to Western thought. This visibility of realities is a step towards constructing dialogues of knowledge, which in turn question the structures of coloniality and 
establish well-being, economic, and social equality conditions, that is, true health as a reflection of life.

\section{CONFLICT OF INTEREST STATEMENT}

The authors state that they are independent of any funding and support institutions and that in conducting the research and writing the manuscript, no interests or values have impacted other than those usual to any research.

\section{AUTHORS' CONTRIBUTIONS}

First author: Research idea, method construction, bibliographic search, article review, result analysis, and writing

Second author: Bibliographic search, article review, and result analysis

Third author: Article review, result analysis, and conclusions

\section{REFERENCES}

1. Betancurth-Loaiza DP, Peñaranda-Correa F. La crianza como asunto fundamental para una salud pública alternativa. Rev Cuba Salud Publica [Internet]. 2016 Sep [cited 2021 May 10];42(3):470483. Available from: http://scielo.sld.cu/scielo.php?script=sci_arttext\&p id=S0864-34662016000300014\&lng=es

2. Almeida-Filho N. Complejidad y Transdisciplinariedad en el Campo de la Salud Colectiva: Evaluación de Conceptos y Aplicaciones. Salud Colect. 2006;2(2):123-146. Available from: https://www.scielosp.org/pdf/scol/2006.v2n2/123146/es

3. Gómez RD. La noción de salud pública: consecuencias de la polisemia. Rev Fac Nac Salud Publica [Internet]. 2002;20(1). Available from: https://www.redalyc.org/articulo.oa?id=12020109

4. Loboa-Rodriguez NJ, Betancurth-Loaiza DP. EI educador de la salud en la salud pública. Rev Salud Publica [Internet]. 2020 Oct [cited 2021 May 10];22(5):e401. Doi:
5. Figueredo N. La Investigación Cualitativa en Ciencias de la Salud: contribuciones desde la etnografía. Enfermería [Internet]. 2017 [cited 2020 Jul 21];6(2):14-19. Available from: http://www.scielo.edu.uy/scielo.php?script=sci_art text\&pid=S2393-66062017000200014

6. Epele M. Sobre las posiciones etnográficas en la antropología de la salud en el sur de las Américas. Salud Colect [Internet]. 2017;13(3):359-373. Doi: https://doi.org/10.18294/sc.2017.1104

7. Landeros-Olvera $\mathrm{E}$, Morales-Rodríguez $\mathrm{MC}$, Martínez-Reyes MC. Una aproximación al cuidado de enfermería desde el enfoque etnográfico. Index Enferm. 2010;19(2-3):187-190. Available from: http://scielo.isciii.es/scielo.php?script=sci_arttext\& pid=S1132-12962010000200025\&lng=es

8. Angrosino M. Etnografía y Observación Participante. Rev. Invest Educ. 2012;13(2):203-208. Available from: https://abacoenred.com/wpcontent/uploads/2016/01/Etnografia-y-

Observacion-Participante.pdf

9. Almudena-Cotán F. El método etnográfico como construcción de conocimiento: un análisis descriptivo sobre su uso y conceptualización en ciencias sociales. Márgenes. 2020;1(1),83-103. Doi: http://dx.doi.org/10.24310/mgnmar.v1i1.7241

10. Guerrero P. Métodos etnográficos: aportes de la antropología y los estudios culturales. Madrid: Editorial Universidad Politécnica Salesiana; 2007. Available from: https://core.ac.uk/download/pdf/84694075.pdf

11. Martínez-Hernáez Á, Gil EP, Comelles JM. Genealogía de la antropología médica en España. RDTP. 2015;70(1):205-233. Doi: https://doi.org/10.3989/rdtp.2015.01.010

12. Muecke M. Sobre la evaluación de las etnografías. Madrid: Siglo XX; 2003. Available from: https://dialnet.unirioja.es/servlet/articulo?codigo= 5776367

13. Wolcott H. En búsqueda de la esencia de la etnografía. Rev Invest Educ Enfermer. 2003;(2):122138. Available from: 
https://www.redalyc.org/comocitar.oa?id=105217 944009

14. Agar M. El extraño profesional: una introducción informal a la etnografía. San Diego CA: Academic Press; 1996. Doi: https://doi.org/10.2307/2067207

15. Valdez-Ayala Z. Etnografía crítica. Surgimiento y repercusiones. Rev Comun. 2012;33(21):16-24. Available from: https://revistas.tec.ac.cr/index.php/comunicacion/ article/view/810

16. Foley D. Valenzuela A. Critical Ethnography. The Politics of Collabor. USA: Sage Publications; 2005. Available from: https://www.umassd.edu/media/umassdartmouth /school-of-education/educational-

leadership/Angela-Valenzuela-article.pdf

17. Scheper-Hughes N. An Essay: AIDS and the social body. Soc Sci Med.1994;39(7):991-1003. Doi: https://doi.org/10.1016/0277-9536(94)90210-0

18. Averill JB. Getting started: Initiating critical ethnography and community-based action research in a program of rural health studies. Int J Qual Methods. 2006;5(2):17-27. Doi: https://doi.org/10.1177/160940690600500206

19. Rappaport J. Más allá de la escritura: la epistemología de la etnografía en colaboración. Rev Colomb Antropol. 2007;43:197-229. Available from: https://www.redalyc.org/articulo.oa?id=10501527 7007

20. Soyini M. Critical Ethnography. Thousand Oaks, CA: Sage, $2012 . \quad$ Doi: http://dx.doi.org/10.4135/9781452233826

21. Thomas J. Doing Critical Ethnography. Newbury Park, CA: SAGE Publications, INC; 1993. Doi: https://dx.doi.org/10.4135/9781412983945

22. Dietz G. Hacia una etnografía doblemente reflexiva: una propuesta desde la antropología de la interculturalidad. Rev Antropol Iberoam. 2011;26(1):3-26. Available from: https://www.redalyc.org/articulo.oa?id=62321332 002

23. Charlotte DA. Reflexive Ethnography. A Guide to Researching Selves and Others. London and New York: Routledge; 1999. Available from: http://resv.hums.ac.ir/uploads/the_asa.pdf

24. Thorne S, Jensen L, Kearney MH, Noblit G, Sandelowski M. Metasíntesis cualitativa: reflexiones sobre la orientación metodológica y la agenda ideológica. Invest Salud Cualit. 2004;14(10):13421365. Doi: http://10.1177/1049732304269888

25. Guber R. El salvaje metropolitano. Buenos Aires: Editorial Paidós; 2004. Available from: http://www.derechoshumanos.unlp.edu.ar/assets/ files/documentos/el-salvaje-metropolitano.pdf

26. Rockwell E. La experiencia etnográfica: historia y cultura en los procesos educativos. Buenos Aires: Paidós; $2009 . \quad$ Available from: https://www.academia.edu/41149812/LA_EXPERIE NCIA_ETNOGR\%C3\%81FICA

27. Ramos-Valencia JM. Políticas públicas para contrarrestar la escalada de las enfermedades Crónico no Transmisibles en México (2001-2015). luris tantum. 2018;(28):1-15. Doi: https://doi.org/10.36105/iut.2018n28.05

28. Galeano J. La investigación social: ¿Para quién?, ¿Para qué?, ¿Cómo? KABUYA . 1999;(9):1-14. Available from: http://www.luguiva.net/\%5C/admin/pdfs/Investiga ci\%C3\%B3n.pdf

29. Vasco-Uribe LG. Entre selva y páramo: viviendo y pensándola lucha indígena. Bogotá: Instituto Colombiano de Antropología e Historia; 2002. Available from: http://www.luguiva.net/libros/detalle.aspx?id=3

30. Geertz C. Local knowledge: further essays in interpretive anthropology. New York: Routledge; $1978 . \quad$ Available from: https://monoskop.org/images/d/d9/Geertz_Cliffor d_Local_Knowledge_Further_Essays_in_Interpretiv e_Anthropology_1983.pdf 
31. Souza MT, Silva MD, Carvalho R. Revisão integrativa: o que é e como fazer integrarive review: what is it? How do it? Einstein. 2010;8(1):102-6. Available from: https://www.scielo.br/pdf/eins/v8n1/1679-4508eins-8-1-0102.pdf

32. Colombia, Ministerio de Salud y Protección Social. Resolución 008430 de 1993 por la cual se establecen las normas científicas, técnicas y administrativas para la investigación en salud. Diario Oficial 23454; 1993 Oct 4. Available from: https://www.minsalud.gov.co/sites/rid/Lists/Bibliot ecaDigital/RIDE/DE/DIJ/RESOLUCION-8430-DE1993.PDF

33. Asamblea Médica Mundial. Declaración de Helsinki 1964. [Internet]. México D.F. [cited 20 Jul 2020]. Available from: http://www.conamed.gob.mx/prof_salud/pdf/helsi nki.pdf

34. Street S. Representación y reflexividad en la (auto)etnografía crítica: ¿voces o diálogos? Nómadas (Col) [Internet]. 2003;(18):72-79. Available from: https://www.redalyc.org/articulo.oa?id=10511789 0009

35. Mata I. Familias vulnerables: la maternidad trasnacional e intensiva de las mujeres migrantes centroamericanas en tránsito por México. Géneros [Internet]. 2020;2(27):181-214. Available from: http://revistasacademicas.ucol.mx/index.php/gene ros/article/view/1716/pdf

36. Apud-Peláez IE. Repensar el método etnográfico. Hacia una etnografía multitécnica, reflexiva y abierta al diálogo interdisciplinario. Antípoda [Internet]. 2013;(16):213-235. Available from: https://www.redalyc.org/articulo.oa?id=81427459 010

37. Govea-Rodríguez V, Vera G, Vargas AM. Etnografía: una mirada desde corpus teórico de la investigación cualitativa. Omnia [Internet]. 2011;17(2):26-39. Available from: https://www.redalyc.org/articulo.oa?id=73719138 003
38. Medina Castro MS. Orientaciones teóricoprácticas para enriquecer la educación de la enfermera desde el cuidado de sí mismo [Internet]. Universidad de La Salle, Bogotá; 2020. Available from:

https://ciencia.lasalle.edu.co/\%0Adoct_educacion_ sociedad/34

39. Deschepper R, Huyghens L, Van Keer RL. Salud mental de pacientes de grupos étnicos minoritarios durante la etapa de cuidado crítico: un estudio etnográfico cualitativo. BMJ. 2017;(7):15-40. Doi: https://10.1136/bmjopen-2016-014075

40. Mon AD. Los cuidados de la salud en personas que viven con diabetes: Enfoque etnográfico antropológico y perspectiva de género. Salud Colect [Internet]. 2017;13(3):375-90. Available from: http://revistas.unla.edu.ar/saludcolectiva/article/vi ew/1156/pdf

41. Bedoya-Ruiz LA, Agudelo-Suárez AA, RestrepoOchoa DA. Relaciones que establecen las mujeres durante el embarazo, parto y posparto con el personal de salud según clase social en Bogotá: estudio cualitativo. Rev Peru Med Exp Salud Publica [Internet]. 2020 Jan [cited 2021 May 10];37(1):7-16. Doi:

http://dx.doi.org/10.17843/rpmesp.2020.371.4963

42. Vega RA. I(nter)dentificación racial: racialización de la salud materna a través del programa Oportunidades y clínicas gubernamentales en México. Salud Colect [Internet]. 2017;13(3):489$505 . \quad$ Available from: http://revistas.unla.edu.ar/saludcolectiva/article/vi ew/1114/1214

43. Linares-Abad M, Moral-Gutiérrez I, Linares-Abad $M$, Sáenz-Monzón E. Educación maternal: un estudio etnográfico en el consultorio de salud de las Fuentezuelas. Cult Cuid. 2002;12(2):33-39. Doi: https://doi.org/10.14198/cuid.2002.12.07

44. Peñaranda-Correa F, Blandón-Loaiza LM. La educación en el programa de crecimiento y desarrollo: entre la satisfacción y la frustración. Rev Fac Nac Salud Pública. 2006;24(2):1-15. Available from: 
http://www.scielo.org.co/scielo.php?script=sci_artt ext\&pid=S0120-386X2006000200004\&Ing=en

45. Chamorro A, Tocornal C. Prácticas de salud en las comunidades del Salar de Atacama: Hacia una etnografía médica contemporánea. Estud Atacamenos. 2005;(30):117-134. Doi: http://dx.doi.org/10.4067/S071810432005000200007

46. Del Carmen A, Olson J, Pasco A. Promoción de la salud y calidad de vida entre madres de preadolescentes: una etnografía enfocada. Rev Latino-Am Enfermagem. 2005;13(spe2):1127-1134. Doi: $\quad$ http://dx.doi.org/10.1590/S010411692005000800005

47. Velandia-Mora MA. Etnología de tres estudios etnográficos sobre la salud y la sexualidad de los(as) jóvenes de las ciudades del Departamento de Santander (Colombia): Mogotes, San Joaquín y El Playón. Cult Cuid. 2008;(24):66-74. Doi: https://10.14198/cuid.2008.24.11

48. Henao S, Restrepo V, Alzate A, González P. Percepción sobre el acceso a los servicios de salud mental que tienen los residentes de tres municipios de Antioquia: 2004- 2006. Rev Fac Nac Salud Publica. 2009;27(3):271- 281. Available from: http://www.scielo.org.co/scielo.php?script=sci_artt ext\&pid=S0120-386X2009000300004\&lng=en

49. Vega RA. Identificación racial: racialización de la salud materna a través del programa Oportunidades y clínicas gubernamentales en México. Salud Colect. 2017;13(3):10-23. Doi: http://10.18294/sc.2017.1114

50. Chacón E. Uso de la etnografía en la prevención y control de las infecciones asociadas a la atención de salud. Rev Chilena Infectol. 2017;34(6):615. Doi: http://dx.doi.org/10.4067/S071610182017000600615

51. O'Byrne P. Population Health and Social Governance: A Review, an Update, Some Clarifications, and a Response. Qual Health Res. 2019;29(5):731-738.
https://doi.org/10.1177/1049732318815686<Cana dà<Enfermería

52. Sandoval-Schmidt ML. Atenção básica e saúde mental: experiência e práticas do Centro de Saúde Escola Samuel B. Pessosa. Cad Psicol Soc Trab. 2013;16(1):57-70. Available from: http://pepsic.bvsalud.org/scielo.php?script=sci_art text\&pid=S1516-

$37172013000100006 \& \operatorname{lng}=p t \& t \operatorname{lng}=p t$

53. Domínguez A. Los cuidados de la salud en personas que viven con diabetes: enfoque etnográfico antropológico y perspectiva de género. Salud Colect. 2017;13(3):375-390. Available from: https://www.scielosp.org/pdf/scol/2017.v13n3/37 5-390

54. McCabe J, Holmes D. Enfermería, salud sexual y jóvenes con discapacidad: una etnografía crítica. Eur J Neurol. 2014;70(1):77-86. Doi: https://10.1111/ene.12167

55. Buitrago MT. Transformaciones de instituciones dedicadas a la atención de personas con discapacidad en Colombia 1970-2010. Rev Fac Med. 2015;63(1):25-34.

Doi: http://dx.doi.org/10.15446/revfacmed.v63n3sup.4 9332

56. Harrowing J, Mikk J. Angustia moral entre las enfermeras ugandesas que brindan atención del VIH: una etnografía crítica. Rev Int Estud Enferm. 2010;47(6):723-731.

Doi: https://doi.org/10.1016/j.ijnurstu.2009.11.010

57. Medina-Castro S. Orientaciones teóricoprácticas para enriquecer la educación de la enfermera desde el cuidado de sí mismo. Bogotá: Editorial Universidad de La Salle; 2020. Available from:

https://ciencia.lasalle.edu.co/cgi/viewcontent.cgi?a rticle $=1036 \&$ context=doct_educacion_sociedad

58. Betancurth DP, Peñaranda F. Un estudio de orientación etnográfica en el marco de la Investigación Acción: un enfoque para comprender la crianza. Univ Humanist. 2018;86:83-105. Doi: https://doi:10.11144/Javeriana.uh86.eoem 
59. Betancurth DP, Peñaranda F. La crianza en situación de injusticia extrema, una comprensión desde un grupo de cuidadoras significativas. Rev Cuba Salud Publica. 2018;44(2):259-277. Available from:

http://www.revsaludpublica.sld.cu/index.php/spu/ article/view/972

60. Bedoya LA, Agudelo DA, Suárez DA. Relaciones que establecen las mujeres durante el embarazo, parto y posparto con el personal de salud según clase social en Bogotá. Rev Peru Med Exp Salud Pública. 2020;37(1):7-16. Doi: http://dx.doi.org/10.17843/rpmesp.2020.371.4963

61. Estrada-Montoya JH, Velosa-Amature LP, JuncaRodríguez C. Recreando la vida desde masculinidades y feminidades democráticas. Invest Cualit Educ. 2019;(1):1-15. Available from: https://proceedings.ciaiq.org/index.php/CIAIQ2019 /article/view/2100/2030

62. Moreno-Rangel LM. Significados y experiencias de la sexualidad y la reproducción en mujeres de la provincia de García Rovira Santander. Medellín: Universidad de Antioquia; 2019. Available from: http://bibliotecadigital.udea.edu.co/bitstream/104 95/13651/1/MorenoLeonor_2019_SexualidadRepr oducci\%C3\%B3nMujeres.pdf

63. Díaz-Bustamante R. Cuerpos bioconstruidos: espacios de participación ciudadana para imaginar y domesticar las corporalidades del mañana. Rev CS. 2018;26:45- $73 . \quad$ Doi: https://doi.org/10.18046/recs.i26.2699

64. Hughes N. La muerte sin llanto. Violencia y vida cotidiana en Brasil. Barcelona: Editorial Ariel, S.A.; 1997. Available from: http://www.psicosocial.net/historico/index.php?op tion=com_docman\&view=download\&alias=274-lamuerte-sin-Ilantoviolencia-y-vida-cotidiana-enbrasil\&category_slug=antropologia\&ltemid $=10022$ 5

65. Álvarez-Romo D, Ocaña JA, Martínez-Pérez AM, León-Sánchez S. Salud intercultural en la atención primaria de salud: un modelo de participación social en Ecuador. Conecta Libertad [Internet]. 2020 Dec
31 [cited 2021 May 10];4(3). Available from: http://revistaitsl.itslibertad.edu.ec/index.php/ITSL/ article/view/148-156

66. Martinez-Hernaez A. Diálogo, etnografía y educación sanitaria. Rev Saude Publica. 2010;44(3):399-405. Doi: https://doi.org/10.1590/s003489102010005000016

67. Ordoñez-Vargas L, Cortés-García CM. Medicalización psiquiátrica en tres prisiones femeninas brasileras: un abordaje etnográfico sobre los itinerarios de criminalización, patologización y farmacologización. Salud Colect. 2020;16:e2507. Doi: https://10.18294/sc.2020.2507

68. Geertz C. La interpretación de las culturas. Barcelona: Gedisa; 2003. Available from: https://antroporecursos.files.wordpress.com/2009 /03/geertz-c-1973-la-interpretacion-de-lasculturas.pdf

69. Hoyos-Vertel LM, Muñoz De Rodríguez L. Barreras de acceso a controles prenatales en mujeres con morbilidad materna extrema en Antioquia, Colombia. Rev Salud Publica [Internet]. 2019 Jan 1 [cited 2021 May 10];21(1):17-21. Available from: https://revistas.unal.edu.co/index.php/revsaludpu blica/article/view/69642

70. Dias-Scopel RP, Scopel D. Promoção da saúde da mulher indígena: contribuição da etnografia das práticas de autoatenção entre os Munduruku do Estado do Amazonas, Brasil. Cad Saude Publica. 2019 [cited 2021 May 10];35(Suppl 3):e00085918. Doi: https://doi.org/10.1590/0102-311×00085918

71. Remorini C, Teves LS, Pasarin L, Palermo ML. Etnografía y salud rural: trayectorias de investigación en los Valles Calchaquíes, Argentina. Anthropologica [Internet]. 2020;38(44):267-96. Doi: https://doi.org/10.18800/anthropologica.202001.0 11

72. Orozco-Castillo ML, López-Díaz AL. Competencia cultural de enfermeras en salud pública con población indígena. Av Enferm. [Internet]. 2019 Jan 
1 [cited 2021 May 10];37(1):9-18. Available from: https://revistas.unal.edu.co/index.php/avenferm/a rticle/view/68513

73. Contatore OA, Tesser CD, Barros NF. Autocuidado autorreferido: contribuições da Medicina Clássica Chinesa para a Atenção Primária à Saúde. Interface (Botucatu) [Internet]. 2021 [cited 2021 May 10];25:e200461. Doi: https://doi.org/10.1590/interface.200461

74. López-Díaz L, Orozco-Castillo L. Cuidado culturalmente competente: puntos de vista de enfermería de salud pública e indígena. Rev Investig Andin [Internet]. 2020 May 28 [cited 2021 May 10];22(40). Available from: https://revia.areandina.edu.co/index.php/IA/articl e/view/1585

75. Chapela M. Promoción de la salud. Un instrumento del poder y una alternativa emancipátoria. México: Universidad Autónoma Metropolitana; 2008. Available from: https://digitalrepository.unm.edu/lasm_cucs_es/1 63
76. Orozco L, Giraldo-Osorio A, Betancurth-Loaiza DP. Saberes populares en salud de las familias campesinas (Colombia). Cult Cuid [Internet]. 2020;24(58):154.

Doi:

http://dx.doi.org/10.14198/cuid.2020.58.14

77. Clua Garcia, R. Aportes del método etnográfico para el diagnóstico de salud de usuarios de drogas adscritos a programas de reducción de daños. Index Enferm. 2020;29(3):147-51. Available from: http://ciberindex.com/c/ie/e12761

78. Foucault M. Un diálogo sobre el poder. Madrid: Alianza editorial; 2000. Available from: https://museo-

etnografico.com/pdf/puntodefuga/181003focault2. pdf 